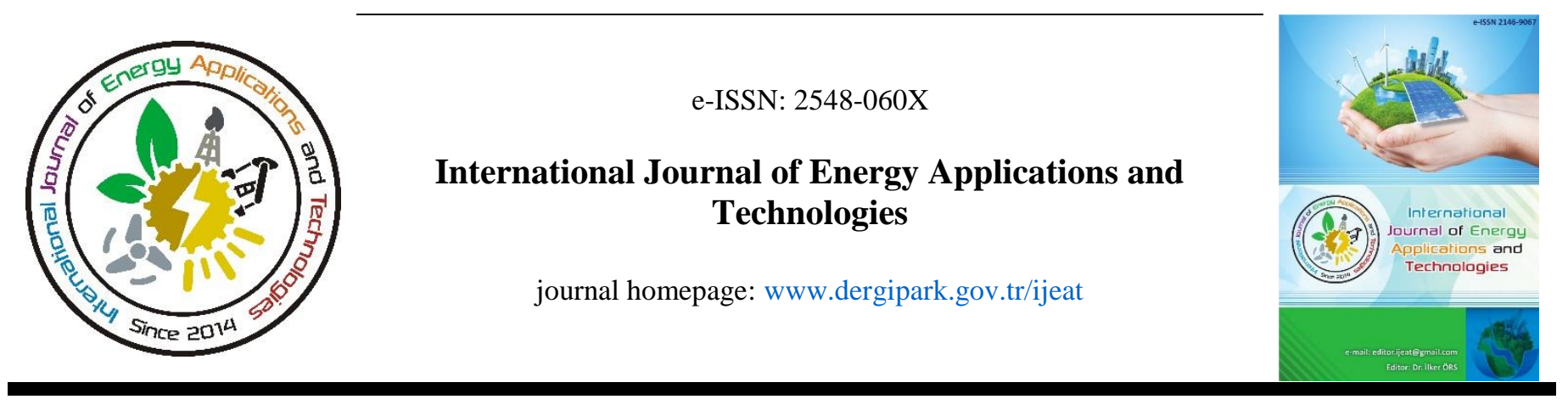

Review Article

\title{
The influences of gasoline and diesel fuel additive types
}

\author{
Ayhan Uyaroğlu*, Mahmut Ünaldı \\ Motor Vehicles and Transportation Technology, Cihanbeyli Vocational School, Selcuk University, Konya Turkey
}

\author{
ARTICLE INFO \\ * Corresponding author \\ ayhan.uyaroglu@selcuk.edu.tr \\ Received September 8, 2020 \\ Accepted January 31, 2021 \\ Published by Editorial Board \\ Members of IJEAT \\ (C) This article is distributed by \\ Turk Journal Park System under \\ the CC 4.0 terms and conditions. \\ doi: 10.31593/ijeat.791973
}

\begin{abstract}
The increasing world population and the level of prosperity have led to an increase in the need for transportation. In the historical process, the increase of the speed of transportation vehicles has been possible with the invention of internal combustion engines. Internal combustion engines are heat engines and use different fuels as an energy source. While combustion of fuel chemical energy transforms to the useful work and is obtained engine power and torque. To increase engine power and torque some innovations have been made for internal combustion engines such as electronic ignition system, fuel injection system, valve timing system and increasing compression ratio etc. On the one hand, these developments lead to increasing engine power and torque, emission regulations obstruct these outputs. Fuel additives are chemical compounds that can help to optimize between emissions and engine power and torque. Moreover, fuel additives are mixed with raw fuel, in order to get improving combustion efficiency, lower fuel consumption, decreasing engine wear, preventing failures, and better running in cold weather. Over and above the types and amounts of fuel additives may alterable depends on the fuel type, fuel producer and climatic factors.
\end{abstract}

\section{Introduction}

The need for transportation increases in proportion to the increase in population and welfare of community. Population growth has both resulted in the strong expansion of existing settlements and leads to has established new settlements. In addition to this, with the increase in the level of welfare, vehicle sales are also increasing. While the world population increased about $11.5 \%$ by $2006-2015$, the number of vehicles in the world increased about $38.3 \%$ by $2006-2015$ [1,2]. The transportation modes are the land, sea and air. Most of the transportation modes use motor vehicles that used fossil fuels commonly. Figure 1. has shown the passenger cars in European Union by the fuel type. According to graph, while the highest percentage of petrol-driven cars are Cyprus (86.1 $\%)$, Finland $(74.9 \%)$ and Hungary $(69.5 \%)$, the highest diesel-driven cars are France (69.3\%), Lithuania (65.2\%),
Luxembourg (64.2\%), Belgium (60\%), Austria and Spain (both, $57 \%$ ), Portugal (54.1\%) and Latvia (53.3\%). In the other respects the pencentage of contribution of alternative fuels are Poland (15.8\%), Lithuania (10\%), Italy (8.3\%) and Latvia $(7.9 \%)$ [3].

Transportation includes not only for passengers but also freights. Therefore, freight transport has a significant share in transportation sector [3]. As shown in Figure 2. road has a large percentage in inland freight transport. Fuel consumption is increasing on account of the means of transportation are mostly use internal combustion engines. Increased fuel consumption is to trigger the increment of using fuel additives as well.

On the other hand, there is increasing research on the use of alternative fuels and additives in internal combustion engines due to environmental concern. Rao et al., 2019, have investigated the performance and emissions of toluene, 
benzene and ethanol blended by $20 \%$ by volumetrically to the gasoline, in their research. They have found the higher brake specific fuel consumption of blended fuels due to lower calorific value of blended fuels at all loads. They have stated the higher brake thermal efficiency with toluene blended fuel among the other blends and also in terms of the emissions, blended fuels have had lower HC and NOx emissions compared to the pure gasoline. They have also pointed out the benzene blended fuel has had increased $\mathrm{CO}$ emissions at all loads [4]. Prabu et al., 2020, have researched combustion, emissions and performance of $\mathrm{CI}$ engine with antioxidants, oxygenates and nanoparticles additives to jatropha biodiesel. They have denoted the reduction of NOx emissions by $30 \%$ with the antioxidants and nanoparticles blended fuels, brake thermal efficiency of oxygenates and nanoparticles blended fuels have nearly equal to that of neat diesel, and also notable decreasement of unburned hydrocarbon by $33 \%$, smoke opacity by $43 \%$ and carbon monoxide by $60 \%$. They have also uttered that with the nanoparticle additives of the test fuels enhanced the air-fuel mixture caused to rapid evoparation that leading to short ignition delay and so improved combustion [5]. Rangabashiam et al. 2020, have analyzed the combustion, emission and performance of neem biodiesel/diesel with DMC (Dimethyl-carbonate) and Pentanol (n-P) oxygenated additives blended by $10 \%$ volume at an equal rate. Neem biodiesel and diesel fuel blending denominated as base fuel and blending ratio $50 \%$ by volume and abbreviated as NBD50D50. DMC10NBD45D45 and P10NBD45D45 test fuels have shown lowered BSFC by 0.4 and $0.5 \mathrm{~g} / \mathrm{kW}$ while increased BTE by 0.3 and $0.6 \%$ compared to the NBD50D50 respectively. In respect to the emissions, they have explained that he pentanol and DMC additives have leaded to decrement in $\mathrm{CO}$ emissions by $4.9 \%$ and $7.4 \%$ at all loads in comparison the NBD50D50 while
DMC and pentanol additives have lowered HC emissions by $3.1 \%$ and $4.7 \%$ compared to the NBD50D50 respectively. DMC and pentanol additives have caused to increasing in peak pressure by 2.3 and 3.1 bar, 3.9 and rising HRR (heat release rate) by $2.1 \mathrm{~J} / \mathrm{CA}$ in comparison the NBD50D50 respectively [6]. Nagappan et al. 2020, have studied the beef tallow methyl ester (BTME) blended by $20 \%$ volume with diesel fuel (B20), 1000 ppm butylated hydroxyanisole (BHA) as mono-phenolic antioxidant added to the blends of B20 (B20 + BHA) and 100\% diesel fuel. According to their test results, B20+ BHA test fuel has shown rising the brake thermal efficiency by $1.8 \%$, reduction brake specific fuel consumption by $2.5 \%$ and has origenated lower NOx emissions by $12.2 \%$ compared to B20 fuel blend [7]. Musthafa et al. 2018, have dredged for the biodiesel produced from palm oil blended with diesel fuel (B20) with and without di-tert-butyl peroxide additive (DTBP) by $1 \%$ by volume, with a view to the thermal efficiency, specific energy consumption, $\mathrm{HC}, \mathrm{CO}$ and $\mathrm{NOx}$ emissions. Their findings about the test fuels are as follows; B20 with additives has rising the thermal efficiency by $2-3.5 \%$ and reducing the specific energy consumption by $10-15 \%$ comparison the B20 and diesel fuel. From the point of view the emissions, B20 fuel with additive has lesser $\mathrm{CO}$ and NOx emissions compared to other B20 and diesel fuel, but B20 with additive has lower $\mathrm{HC}$ emissions from the diesel fuel and higher from the B20 fuel [8].

Table 1. shows the main features of automotive fuels. Expected features from fuels are good combustion quality, good performance at high and low temperatures, high heat of combustion, materials compatibility, minimized deposit formation, low foaming tendency, stability and suitable latent heat of vaporization. These characteristics affect the engine and vehicle performance in different ways.

Table 1. Main features of automotive fuels [9]

\begin{tabular}{|l|l|}
\hline \multicolumn{1}{|c|}{ Feature } & \multicolumn{1}{|c|}{ Relationship with engine and vehicle performance } \\
\hline $\begin{array}{l}\text { Good combustion } \\
\text { quality }\end{array}$ & $\begin{array}{l}\text { Better ignition and combustion qualities, lead to better vehicle fuel economy and less emission of } \\
\text { pollutants. High octane or cetane numbers are critically important for good combustion quality in SI or } \\
\text { CI engines }\end{array}$ \\
\hline $\begin{array}{l}\text { Good performance at } \\
\text { high and low } \\
\text { temperatures }\end{array}$ & $\begin{array}{l}\text { A fractional composition of fuel must enable easy cold start, good driveability, fuel economy, low } \\
\text { exhaust and evaporative emissions, and reliable hot re-starting without lubricant dilution in a wide range } \\
\text { of ambient conditions. Usually, fuels are blended appropriately for both seasonal and geographical } \\
\text { variations in temperature }\end{array}$ \\
\hline $\begin{array}{l}\text { High heat of } \\
\text { combustion }\end{array}$ & A smaller fuel quantity needs to be carried in the vehicle tank when its chemical energy content is high \\
\hline Materials compatibility & Materials compatibility is essential for the preventing corrosion of fuel system components \\
\hline $\begin{array}{l}\text { Minimized deposit } \\
\text { formation }\end{array}$ & $\begin{array}{l}\text { Assists in maintaining engines close to their designed optimal efficiency and relieve the deterioration of } \\
\text { performance, fuel economy and emissions. Deposit control additives are low-cost, widely recognized } \\
\text { means for suppressing deposit formation }\end{array}$ \\
\hline Low foaming tendency & $\begin{array}{l}\text { Low foaming tendency is relevant for diesel fuels, enabling faster vehicle refueling with lower } \\
\text { evaporative emissions }\end{array}$ \\
\hline Stability & $\begin{array}{l}\text { Better fuel stability enables to minimize deposit formation and to store fuel without deterioration longer } \\
\text { periods of time }\end{array}$ \\
\hline $\begin{array}{l}\text { Suitable latent heat of } \\
\text { vaporization }\end{array}$ & $\begin{array}{l}\text { High latent heat of vaporization causes the charge to be cooled and therefore become denser. However, } \\
\text { there is danger of freezing ambient moisture in the carburettor }\end{array}$ \\
\hline
\end{tabular}




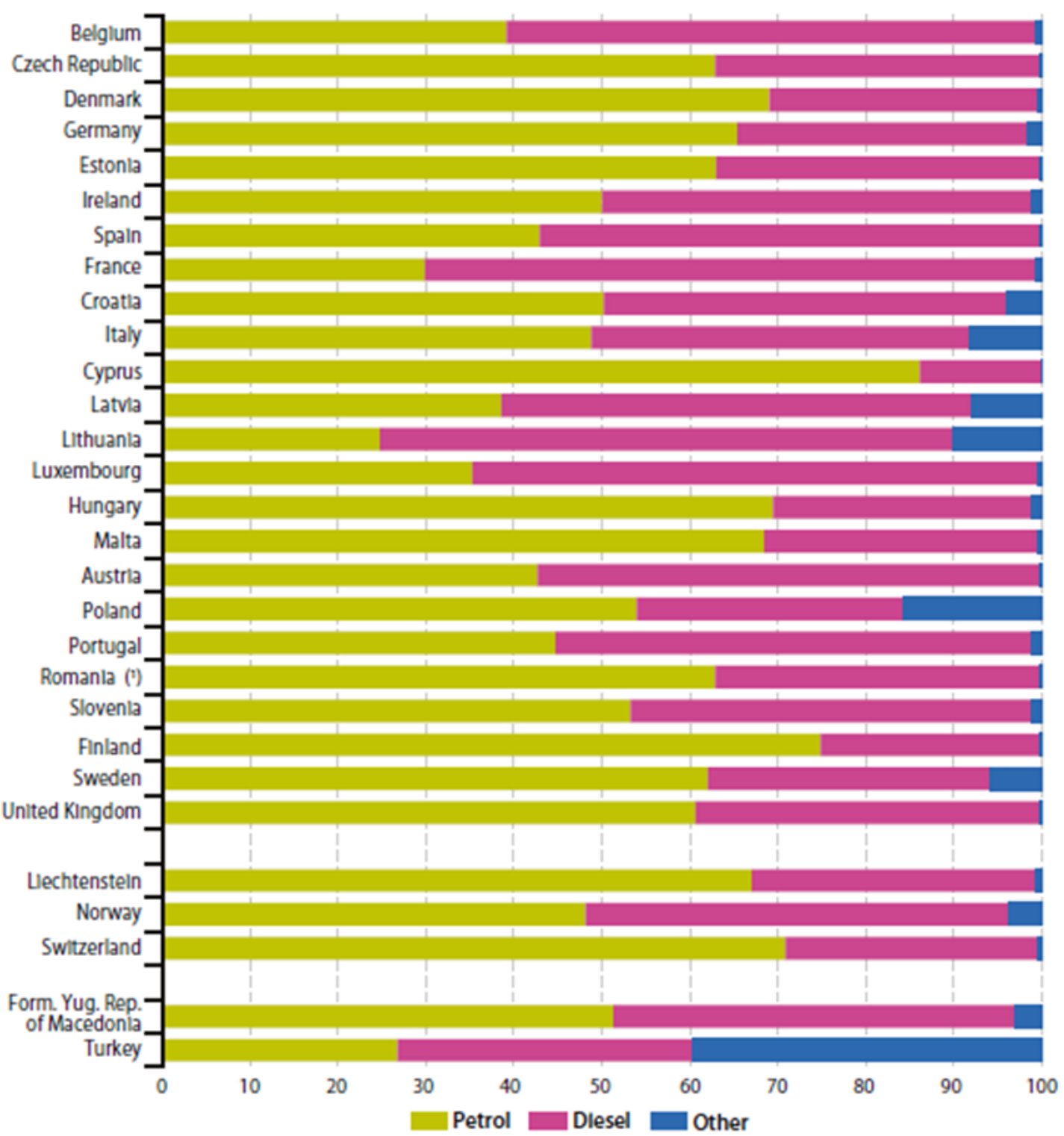

Fig. 1. Passenger cars by fuel type, 2016 (\%) [3]

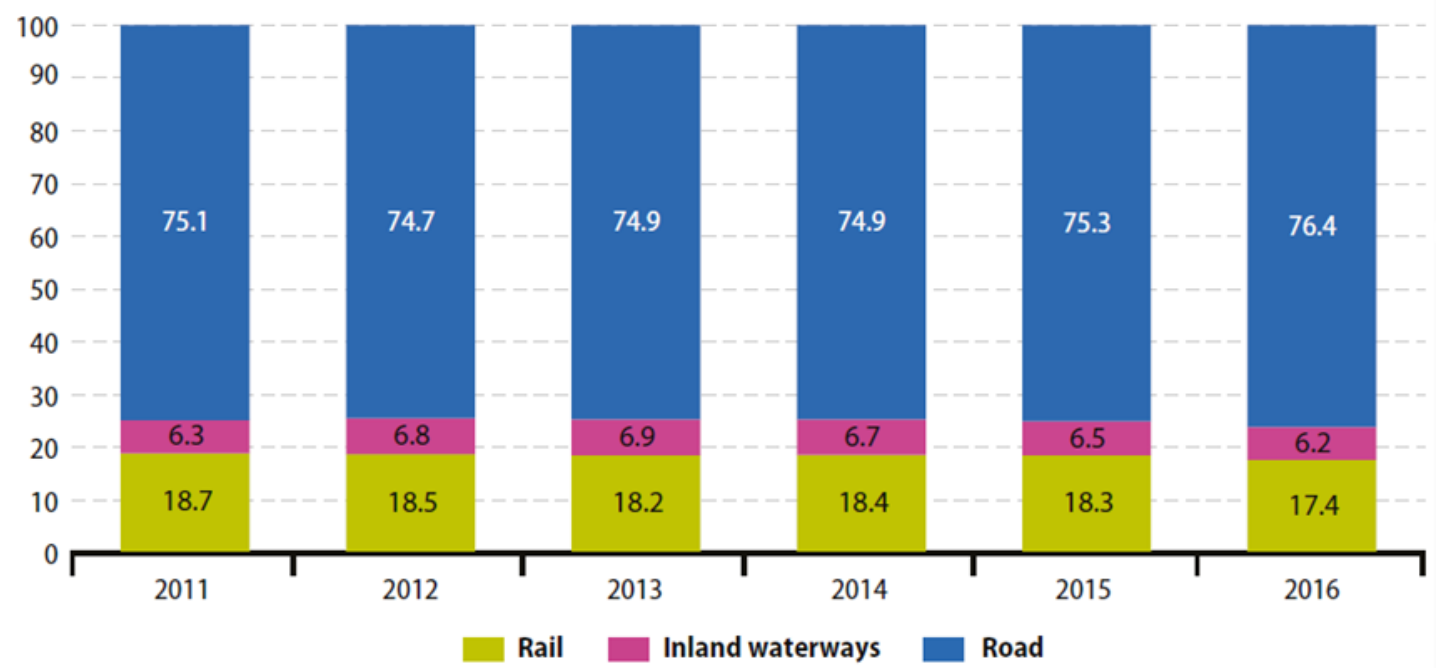

Fig. 2. Modal split of inland freight transport, EU28, 2011-2016 (\% share in tonne-kilometres) [3] 
Figure 3. shows the consumption of petroleum products in 28 European countries (EU-28). According to figure, the most consumption is occurred in diesel fuel between the 1990 and 2016. In addition, petroleum products consumption in the last five years has fallen below the 1990s. On the other hand, the
Renewable Energy Directive (RED) stipulates that at least $10 \%$ of all energy in road transport fuels and $20 \%$ of all energy usage in the EU should be produced from renewable sources by 2020 [10].

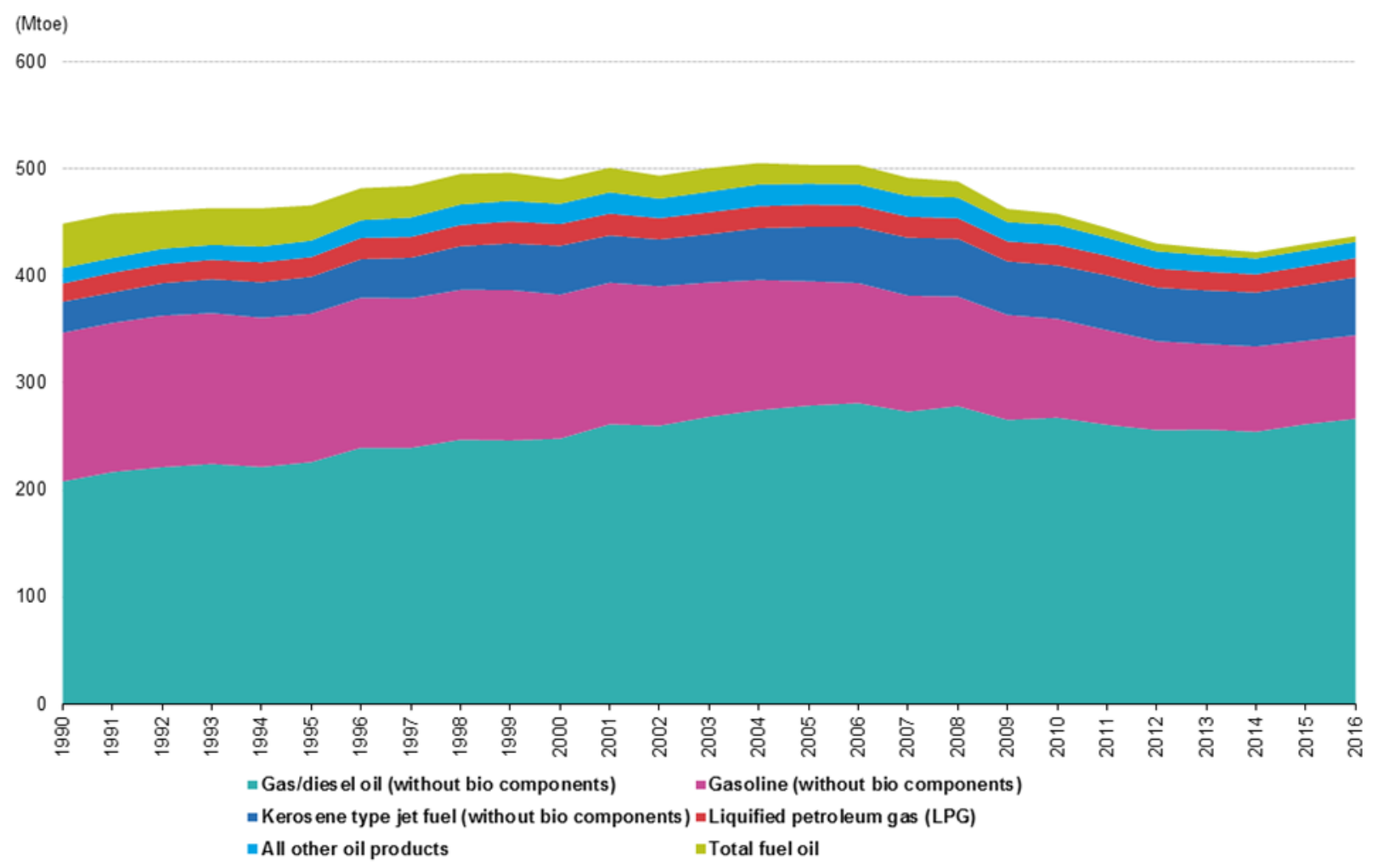

Fig. 3. Variation of fuel consumptions by types (Million Tonnes of Oil Equivalent) [11]

Fuel additives are chemical compounds which can enhance fuel performance and correct deficiency, if added in lower concentrations typically $<1 \%$ at the refineries are called refinery (functional) additives or if added in high concentrations typically $>1 \%$ are called blending components [12,13]. Table 2. has shown the diesel and gasoline fuel additives and their functions. Additive amounts are changed depend on the fuel types. Additive usage may be divided into three major categories: a) to satisfy desired levels of performance in engines, b) to ensure the delivery of pristine, specification fuels to the end user c) obtain required chemical/physical properties as produced by refiner [12]. From the economic consideration petroleum additive industry is one of the operating sectors of the world economy. The world wide turnover of the petroleum additive industry is about to $€ 7,000$ million ( $€ 1,900$ in million Europe), and the expenditure of the research and development (R\&D) in 2005 is $€ 400$ million ( $€ 115$ million in Europe). In terms of employment opportunity, 8,400 direct employees worldwide (2,800 in Europe), going concern various $75 \mathrm{R} \& D$ and manufacturing sites globally (25 in Europe) [14].

When analyzed the benefits of fuel additives for refiner and end user from the Table 3. the anticipation distinctions stand out. End users prospect the more power but less fuel, and trouble-free use, long-lasting, durability and environment friendly. From the point of view of refiner, benefits of fuel additives are reduced maintenance and process losses, prolonged life of facilities, optimized operations, operational flexibility, upgrading of lower value streams and trimming adjustments to meet specifications.

Since the transportation is an indispensable need, usage of motor vehicles is also vital. In addition, internal combustion engines have overwhelming majority in the transportation modes. Therefore, fuel consumption and hence the use of fuel additive will increase. This overview paper can provide technical summary for those related to this field. 
Table 2. Diesel fuel and Gasoline additives and their functions [13]

\begin{tabular}{|c|c|c|c|c|c|}
\hline \multicolumn{3}{|c|}{ Gasoline additives and their functions } & \multicolumn{3}{|c|}{ Diesel fuel additives and their functions } \\
\hline Additive & Functions & $\begin{array}{l}\text { Treat Level } \\
(\mathrm{mg} / \mathrm{kg})\end{array}$ & Additive & Functions & $\begin{array}{l}\text { Treat Level } \\
(\mathrm{mg} / \mathrm{kg})\end{array}$ \\
\hline Antiknock additives & Increase of octane number & $10-1000$ & Cetane improvers & $\begin{array}{l}\text { Increase cetane number (easier cold start, lower } \\
\text { emissions, noise, and fuel consumption, longer } \\
\text { engine life time) }\end{array}$ & $100-300$ \\
\hline $\begin{array}{l}\text { Combustion } \\
\text { improvers }\end{array}$ & Improve combustion characteristics & $5-50$ & Combustion improvers & $\begin{array}{l}\text { Lower emission (improve combustion of particle } \\
\text { matters) }\end{array}$ & $10-30$ \\
\hline $\begin{array}{l}\text { Detergents and } \\
\text { dispersants }\end{array}$ & $\begin{array}{l}\text { Additives to clean and keep clean } \\
\text { (injection and exhaust system) }\end{array}$ & $20-1000$ & $\begin{array}{l}\text { Deposit control } \\
\text { additives }\end{array}$ & $\begin{array}{l}\text { Additives to clean and keep clean, inhibit deposit } \\
\text { formation; decrease fuel consumption and } \mathrm{CO}_{2} \\
\text { emission }\end{array}$ & $30-330$ \\
\hline $\begin{array}{l}\text { Octane requirement } \\
\text { increase inhibitor }\end{array}$ & $\begin{array}{l}\text { Inhibit octane requirement increase by } \\
\text { removing deposits in combustion } \\
\text { chamber }\end{array}$ & $20-100$ & Antioxidants & $\begin{array}{l}\text { Prevent resin and inhibit deposit formation, } \\
\text { increase storage stability }\end{array}$ & $5-30$ \\
\hline Corrosion inhibitors & Corrosion protection of fuel system & $5-50$ & Corrosion inhibitors & Corrosion protection of fuel system & $10-20$ \\
\hline Antioxidants & $\begin{array}{l}\text { Increase storage stability, prevent resin } \\
\text { formation }\end{array}$ & $10-50$ & Metal deactivators & $\begin{array}{l}\text { Deactivation of metal surfaces that act as } \\
\text { oxidation catalysts; increase storage stability, } \\
\text { decrease the catalytic effect of especially the } \\
\text { copper ions }\end{array}$ & $5-20$ \\
\hline Metal deactivators & $\begin{array}{l}\text { Deactivation of metal surfaces that act as } \\
\text { oxidation catalysts }\end{array}$ & $5-20$ & Demulsifiers & $\begin{array}{l}\text { Prevent, inhibit, and terminate the haze formation } \\
\text { caused by water or insoluble compounds }\end{array}$ & $10-20$ \\
\hline Antiwear additives & Decrease wear (e.g., of fuel pump) & $10-50$ & Lubricity improvers & $\begin{array}{l}\text { Increase lubricity in cases of low sulfur and } \\
\text { decrease final boiling point of gasoils (fuel pump) }\end{array}$ & $25-100$ \\
\hline Friction modifiers & $\begin{array}{l}\text { Fuel saving by decrease friction } \\
\text { between moving parts }\end{array}$ & $30-50$ & Cloud point depressants & $\begin{array}{l}\text { Decrease initial temperature of parafin } \\
\text { crystallization }\end{array}$ & $150-500$ \\
\hline $\begin{array}{l}\text { Dehazers } \\
\text { (demulsifiers) }\end{array}$ & $\begin{array}{l}\text { Inhibit haze formation (promote water } \\
\text { coalescence) }\end{array}$ & $3-50$ & Pour point depressants & Decrease pour point & $75-350$ \\
\hline De-icing additives & Inhibit ice formation in carburetor & $5-30$ & $\begin{array}{l}\text { Flow improvers/wax } \\
\text { crystal modifiers/wax } \\
\text { dispersants }\end{array}$ & Ensure favorable cold flow properties & $150-500$ \\
\hline Antistatic agents & Increase conductivity & $2-10$ & $\begin{array}{l}\text { Wax-antisettling- } \\
\text { additive }\end{array}$ & Inhibit paraffin settlement & $100-200$ \\
\hline Dyes & Differentiate fuels & $2-20$ & Friction modifiers & Reduce friction (lower fuel consumption) & $50-100$ \\
\hline & & & De-icing Additives & Inhibit ice crystal formation & $2-10$ \\
\hline & & & Biocides & $\begin{array}{l}\text { Suppress formation of microorganisms and } \\
\text { bacteria to prevent quality degradation }\end{array}$ & $1-10$ \\
\hline & & & Antifoam agents & Inhibit foam formation during filling & $1-5$ \\
\hline & & & Antistatic agents & Increase conductivity & $2-10$ \\
\hline & & & Deodorants & Suppress or neutralize odors & $5-10$ \\
\hline & & & Dyes & Differentiation of fuels & $5-10$ \\
\hline
\end{tabular}


Table 3. Fuel Additive benefits for refiner and end user [12]

\begin{tabular}{|l|l|}
\hline $\begin{array}{l}\text { Fuel additive benefits to the } \\
\text { refiner }\end{array}$ & $\begin{array}{l}\text { Fuel additive benefits for the } \\
\text { end user - gasoline and diesel }\end{array}$ \\
\hline Optimized operations & Power output \\
\hline Operational flexibility & Fuel economy \\
\hline $\begin{array}{l}\text { Upgrading of lower value } \\
\text { streams }\end{array}$ & Maintenance \\
\hline Prolonged life of facilities & Effective emissions control \\
\hline Maintaining process efficiency & Engine life \\
\hline Reduced process losses & $\begin{array}{l}\text { Driveability } \\
\text { a) Cold start and warm-up } \\
\text { b) Stalling and hesitation } \\
\text { c) Smooth operation }\end{array}$ \\
\hline Reduced maintenance & \\
\hline $\begin{array}{l}\text { Trimming adjustments to meet } \\
\text { specifications }\end{array}$ &
\end{tabular}

\section{Diesel/Biodiesel Additives}

\subsection{Metal based additives}

Metal-based additives used in diesel/biodiesel fuels improve the combustion due to catalyst effect and so results in decreasing fuel consumptions and emissions. Several metalbased additives include platinum $(\mathrm{Pt})$, cerium $(\mathrm{Ce})$, iron $(\mathrm{Fe})$, barium $(\mathrm{Ba})$, cerium-iron $(\mathrm{Ce}-\mathrm{Fe})$, calcium, platinumcerium $(\mathrm{Pt}-\mathrm{Ce})$, manganese $(\mathrm{Mn})$, copper $(\mathrm{Cu})$, aluminum $(\mathrm{Al})$, magnesium $(\mathrm{Mg})$, silver $(\mathrm{Ag})$, gold $(\mathrm{Au})$, boron $(\mathrm{B})$, graphene, silica $(\mathrm{Si})$ etc. The other metal-based additives used for fuel borne catalyst are Nano $\mathrm{CuO}, \mathrm{CuCl}_{2}, \mathrm{CoCl}_{2}$, $\mathrm{FeCl}_{3}$ and $\mathrm{CuSO}_{4}$. Other than these metal oxides such as aluminum oxide $\left(\mathrm{Al}_{2} \mathrm{O}_{3}\right)$, calcium carbonate $\left(\mathrm{CaCO}_{3}\right)$, cobalt oxide $\left(\mathrm{Co}_{3} \mathrm{O}_{4}\right)$, cerium oxide $\left(\mathrm{CeO}_{2}\right)$, titanium oxide $\left(\mathrm{TiO}_{2}\right)$, zinc oxide $(\mathrm{ZnO})$, copper oxide $(\mathrm{CuO})$, and alloys of metals like magnalium (Mg-Al), Carbon nano tubes (CNT) are also used as additives. Metal-based additives have positive impacts on reduce of exhaust emission on account of the fact that two different mechanisms such as acting as catalyst with carbon atoms thereby decreasing the oxidation temperature and/or react with water molecules to produce hydroxyl radicals that enhance the soot oxidation [15-36].

\subsection{Oxygenated additives}

Combustion reaction needs to oxidizing agent, and oxygen is existed naturally in the world atmosphere as an oxidizer. On the other hand, insufficient supply of oxygen causes incomplete combustion, but oxygenated additives provide to enhance the combustion quality and octane rating. Mostly used oxygenated additives are alcohol (methanol, ethanol, propanol, butanol, etc.), ethers (ethyl tert-butyl ether, methyl tert-butyl ether, diisopropyl ether, dimethyl ether, diethyl ether, etc.), esters (dicarboxylic acid esters and acetoacetic esters). Oxygenated additives affect attributes such as oxygen content of the fuel and decreasing the ignition temperature due to its oxygen presence, and also viscosity, density, volatility, cetane number and low temperature behaviors.
Since the oxygen content of oxygenated additives allows the combustion in the engine more efficiently, smoke emission reduces. Moreover, oxygenated additives have some restrictions such as lower calorific value, low cetane number, insufficient lubricating behaviors, slightly higher NOx emissions, high heat of vaporization and auto-ignition temperature, immiscibility and instability with diesel fuel [33-43].

\subsection{Antioxidant additives}

Oxidation is occurred contacting with the oxygen molecules. Oxidation of fuel leads to deterioration of the fuel that is fuel darkening, formation of gums and sediments, or the formation of organic acids and aldehydes. These products are thought to cause the engine and injection problems. Biodiesel includes unsaturated methyl esters particularly poly-unsaturated methyl esters which can be readily oxidized like methyl linoleate (C18: 2) and methyl linolenate (C18: 3), which causes acids, aldehydes, esters, ketones, peroxides and alcohols formation that is decomposed compounds. BHA (Butylated hydroxyanisole), BHT (Butylated hydroxytoluene), DPA (diphenylamine), PA (Pyrogallol), PG (Propyl gallate) and TBHQ (Tert-butyl hydroquinone), are antioxidants additives used in diesel-biodiesel blends due to prevent auto-oxidation and also antioxidants can reduce NOx formation. Density, viscosity, and acid value of biodiesel and diesel-biodiesel blend increase after the oxidation, while iodine value decreases with increasing storage time [33-36, 44-56].

\subsection{Cold flow improver additives}

Cloud point (CP), cold filter plugging point (CFPP), and pour point (PP) are the cold flow properties related to the behavior of fuel flow at low temperatures. It is known that biodiesel fuels more prone to gelling and thicken at lower temperatures compared to diesel fuel. In cold weather conditions biodiesel wax content starts freezing and crystal structure occurs which affects flowability or ability to be pumped and cold filter plug point (CFPP). Biodiesel cold flow properties are associated with biodiesel features such as the oil feedstock, type of alcohol used, impurities and quantity of bound glycerin in biodiesel. Ethylene vinyl acetate copolymer, glycerol ketals, glycerol acetates, phthalimide, succinimide copolymers, and olefin-ester copolymers and dispersants which may be combined with EVA (Ethylene vinyl acetate) are the additives that used in improving the cloud point via preventing the crystal growth [33-34, 36, 57-60].

\subsection{Cetane number improver additives}

Basically, the time period between the start of injection and start of combustion is called ignition delay. There is an inverse relationship between the cetane number and ignition delay. In other words, as the cetane number increases the 
ignition delay decreases. Higher speed diesel engines need to higher cetane numbers from 48 to 67 . To achieve effectively operation in high speed diesel engines, fuels with high cetane number are required. Low cetane number tends to cold-start problems, low power, high engine noise, increased fuel consumption, white smoke emission and higher exhaust emissions. Enhanced the cetane number of the fuel, decreases the ignition temperature, and also leads to reduce NOx emissions. Nitrates (2-ethylhexyl nitrate, octyl nitrate, isopropyl nitrate, amyl nitrate), nitro alkanes, nitro carbonates, peroxides, aldehydes, tetra-azoles, etc., are used as additives for improving cetane number. The most used cetane improver additives are 2-ethyl hexyl nitrate (2-EHN) and tertiary butyl peroxide [33-36, 61-62].

\subsection{Lubricant additives}

The environmental effects of sulfur such as acid rain and air pollution are known. For this reason, sulfur in diesel fuel is decreased from firstly $5000 \mathrm{ppm}$ and then $500 \mathrm{ppm}$ to $15 \mathrm{ppm}$ over time in USA. 5000 ppm sulfur level in diesel fuel until 1993 is called diesel fuel. 500 ppm sulfur is called low sulphur diesel fuel between 1993 and 2006. 15ppm sulfur in diesel is known as ULSD (Ultra-low sulfur diesel) after 2006 [63]. Due to decreased sulfur level of fuel is lead to need for additives for lubricity performance. Lubricity prevents the friction between moving parts. Fuel lubricity additives can reduce the wear of fuel pump and injectors. Lubricant additives in other words surface active compounds can be examined in two parts, first one is an active polar head group which provides the protective film on engine moving parts, the second one is the hydrocarbon tail providing fuel solubility. Lubricant additives are fatty acid esters (including FAME), unsaturated fatty acids dimers, aliphatic amines, and long chain monocarboxylic acids [34-36].

The effects of fuel additive types are explained above. However, fuel additives not only have many advantages to help the improvement of some fuel properties, but also have disadvantages. Table 4. shows the advantages and disadvantages of fuel additives.

\section{Conclusions}

Pure fuels are insufficient to meet today's performance and emission expectations. Nevertheless, biofuel ratio in the fuels is increased due to promoting by the governments. Increased biofuel ratio will change the fuel properties, and this new blended fuels will need to additives to ensure the expected specifications. The following conclusions can be obtained from this study: additives treat level can change by the types of fuel. The purposes of fuel additive use are to provide fuel economy, sufficient engine performance, storage stability, lower emissions, corrosion inhibitor, minimum deposit and foam formation, protecting from contamination, suitability at high and low temperatures, reduced wear and engine life. As a result, expectations of end user and refiners can not meet without usage of additives. It is foreseen that research on additives will increase due to emission restrictions.

\section{Acknowledgment}

This article is produced from the" Benefits of Fuel Additives Used in Internal Combustion Engines ", which was presented as oral presentation at the 3rd Annual International Mechanical Engineering Conference held in Athens Greece between 22-25 July 2019 and its abstract is published in the conference abstract book. Appreciations to Selcuk University Scientific Research Projects Unit (Project No: 19401027) for support this study.

\section{$\underline{\text { ORCID }}$}

A. Uyaroğlu

0000-0001-7914-9665

M. Ünald1

0000-0003-2144-8085 
Table 4. Comparison of the advantages and disadvantages of fuel additives [36]

\begin{tabular}{|c|c|c|}
\hline Type of additive & Advantages & Disadvantages \\
\hline Antioxidant additives & $\begin{array}{l}\text { - Higher density and kinematic viscosity and consequenty } \\
\text { injection of a larger mass of fuel to the engine for the } \\
\text { same fuel volume } \\
\text { - Increased cetane number } \\
\text { - Increased flash point } \\
\text { Increased stability of biodiesel without causing any } \\
\text { significant negative effects on its physicochemical } \\
\text { properties } \\
\text { - Inhibiting the oxidation of other molecules } \\
\text { - } \text { Maintaining biodiesel quality during long-term storage } \\
\text { reacting with aromatic amines. Peroxyl free radical } \\
\text { formations have been reported as one of the main causes } \\
\text { of the higher NOx emissions of biodiesel }\end{array}$ & $\begin{array}{l}\text { Decreased calorific value } \\
\text { Increases in CO emissions due to the } \mathrm{OH} \\
\text { radicals (oxidation inhibitor) in the chemical } \\
\text { structure of antioxidants } \\
\text { - Lower heat energy content of the antioxidant } \\
\text { containing blends } \\
\text { - Some increases in } \mathrm{HC} \text { emission due to reduced } \\
\text { formation of oxidative free-radicals }\end{array}$ \\
\hline $\begin{array}{l}\text { Cetane number } \\
\text { improver additives }\end{array}$ & $\begin{array}{l}\text { - Accelerating ignition in combustion chamber which } \\
\text { results in shorter ignition delay time and, thus decreased } \\
\text { NOx formation } \\
\text { - Higher engine stability, better combustion efficiency, } \\
\text { and lower release of emissions } \\
\text { - Improvements in fuel viscosity } \\
\text { - More efficient cold start in addition to lower combustion } \\
\text { noise and long life of the engine } \\
\text { - Providing a cost effective increase in biodiesel cetane } \\
\text { quality }\end{array}$ & $\begin{array}{l}\text { Decreased cooling effect inside the cylinder } \\
\text { leading to increased HC emissions } \\
\text { - Increases in diffusion combustion in rich fuel- } \\
\text { air regions leading to increased CO emissions }\end{array}$ \\
\hline $\begin{array}{l}\text { Cold flow improver } \\
\text { additives }\end{array}$ & $\begin{array}{l}\text { - Averting tank and fuel line heating systems } \\
\text { - }\end{array}$ & $\begin{array}{l}\text { Precipitation of paraffin crystals modified in } \\
\text { the presence of these additives, as a result of } \\
\text { their higher density value vs. the liquid portion. } \\
\text { These crystals may settle sown during storage } \\
\text { leading to the formation of a paraffin-rich layer } \\
\text { at the bottom of the tank }\end{array}$ \\
\hline Metal-based additives & 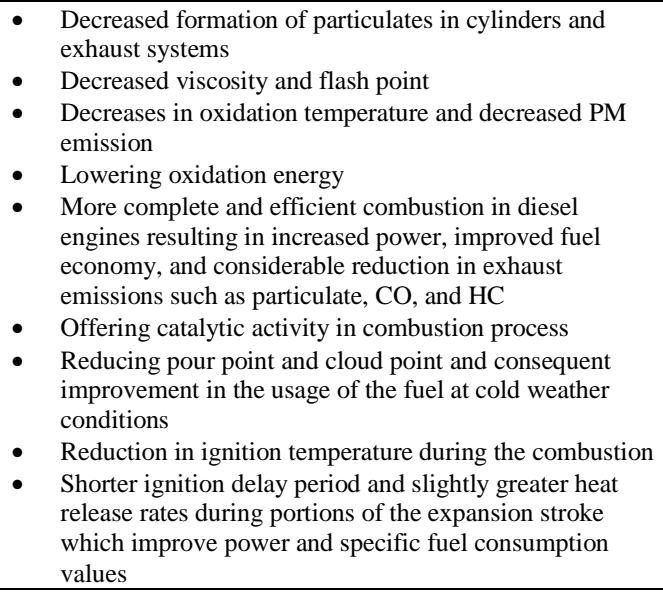 & $\begin{array}{l}\text { Dissolution in fuels at ultra-low rates } \\
\text { Increases in NOx emission probably owing to } \\
\text { the catalyst effect of metallic additives on } \\
\text { combustion process }\end{array}$ \\
\hline $\begin{array}{l}\text { Lubricity improver } \\
\text { additives }\end{array}$ & $\begin{array}{l}\text { Effective in restoring the lubricity lost in severe refinery } \\
\text { processing, thereby permitting normal engine operation, } \\
\text { reliability, and service life } \\
\text { - Formation of a protective film on moving metal surfaces } \\
\text { and a hydrocarbon tail to assist fuel solubility }\end{array}$ & $\begin{array}{l}\text { Some lubricity improver additives are known } \\
\text { to have only limited solubility in fuel after } \\
\text { prolonged storage at low ambient temperatures } \\
\text { Some lubricity improver additives have a } \\
\text { relatively high cloud point, leading to } \\
\text { precipitation at normal winter ambient } \\
\text { temperatures. Hence, dilution or heated storage } \\
\text { may be required }\end{array}$ \\
\hline Oxygenated additives & $\begin{array}{l}\text { - An efficient solution to overcome the incomplete } \\
\text { combustion phenomenon and to reduce diesel engine } \\
\text { emissions especially PM emission } \\
\text { - Higher brake thermal efficiency } \\
\text { - Improvement in fuel viscosity } \\
\text { - Shorter ignition delays }\end{array}$ & $\begin{array}{l}\text { - } \quad \text { Carcinogenicity of some oxygenated additives } \\
\text { such as tertiary butyl ether } \\
\text { - Decreased caloric value } \\
\text { - } \quad \text { Diminished combustion temperatures which } \\
\text { could potentially lead to weakened rate of } \\
\text { biodiesel oxidation reaction in the chamber and } \\
\text { subsequently, deteriorated combustion } \\
\text { efficiency } \\
\text { - Diminished ignition temperature } \\
\text { - Less stability and emulsifiers/surfactants need } \\
\text { to be added and to prevent phase separation }\end{array}$ \\
\hline
\end{tabular}




\section{References}

[1] World population,

2019.

from:

http://www.worldometers.info/world-population/world population-by-year/.

[2] Number of passenger cars and commercial vehicles in use worldwide, $2019 . \quad$ from: https://www.statista.com/statistics/281134/number-ofvehicles-in-use-worldwide/.

[3] Eurostat, P. 2018. Energy, transport and environment indicators-2018 edition. Publications Office of the European Union, Luxembourg.

[4] Srinivas Rao, T., Jakeer Hussain, S., Dhana Raju, V., Venu, H., \& Subramani, L. 2019. Experimental assessment of various fuel additives on the performance and emission characteristics of the spark ignition engine. International Journal of Ambient Energy, 1-6.

[5] Prabu, A., Premkumar, I. I., \& Pradeep, A. 2020. An investigation on the performance, combustion and emission characteristics of CI engine on the addition of antioxidants, oxygenates and nanoparticles as additives in Jatropha biodiesel. International Journal of Ambient Energy, 41(2), 121-128.

[6] Rangabashiam, D., Munuswamy, D. B., Duraiswamy Balasubramanian, S., \& Christopher, D. 2020. Performance, emission, and combustion analysis on diesel engine fueled with blends of neem biodiesel/diesel/additives. Energy Sources, Part A: Recovery, Utilization, and Environmental Effects, 1-11.

[7] Nagappan, B., Devarajan, Y., Kariappan, E., Philip, S. B., \& Gautam, S. 2020. Influence of antioxidant additives on performance and emission characteristics of beef tallow biodiesel-fuelled CI engine. Environmental Science and Pollution Research, 1-15.

[8] Musthafa, M. M., Kumar, T. A., Mohanraj, T., \& Chandramouli, R. 2018. A comparative study on performance, combustion and emission characteristics of diesel engine fuelled by biodiesel blends with and without an additive. Fuel, 225, 343-348.

[9] Sher, E. Handbook of air pollution from internal combustion engines: pollutant formation and control. Academic Press, 1998.

[10] EU-Fuels-Biofuel-Policy, $2019 . \quad$ from: https://www.transportpolicy.net/standard/eu-fuels biofuel-policy/

[11] Oil and petroleum products - a statistical overview, 2019. from: https://ec.europa.eu/eurostat/statisticsexplained/index.php?title=Oil_and_petroleum_products__a_statistical_overview\#Use_of_petroleum_products.

[12] Tupa, R. C., \& Dorer, C. J. 1984. Gasoline and diesel fuel additives for performance/distribution/quality (No. 841211). SAE Technical Paper.
[13] Srivastava, S. P., \& Hancsok, J. Fuels and fueladditives. John Wiley \& Sons, 2014.

[14] Fuel Additives: Use and Benefits. September 2013 / ATC Document 113. Technical Committee of Petroleum Additive Manufacturers in Europe.

[15] Jelles, S. J., Makkee, M., \& Moulijn, J. A. 2001. Ultra low dosage of platinum and cerium fuel additives in diesel particulate control. Topics in catalysis, 16(1-4), 269-273.

[16] Jung, H., Kittelson, D. B., \& Zachariah, M. R. 2005. The influence of a cerium additive on ultrafine diesel particle emissions and kinetics of oxidation. Combustion and flame, 142(3), 276-288.

[17] Zhao, H., Ge, Y., Zhang, T., Zhang, J., Tan, J., \& Zhang, H. 2014. Unregulated emissions from diesel engine with particulate filter using Fe-based fuel borne catalyst. Journal of Environmental Sciences, 26(10), 2027-2033.

[18] Bati, Z. A., \& Altun, S. 2020. Investigation of the effect of barium-based additive on smoke and NO x emissions of a diesel engine fueled with conventional and biodiesel fuels. Clean Technologies and Environmental Policy, 1-11.

[19] Campenon T, Wouters P, Blanchard G, Macaudiere P, Seguelong T. 2004. Improvement and simplification of DPF system using a ceria-based fuel borne catalyst for diesel particulate filter regeneration in serial applications. SAE Paper:2004-01- 0071.

[20] Walter, R. M., \& Edward, A. H. 2005. Catalyst for Improving the Combustion Efficiency of Petroleum Fuels in Diesel Engines. In th Diesel Engine Emissions Reduction Conference, August (pp. 21-25).

[21] Okuda, T., Schauer, J. J., Olson, M. R., Shafer, M. M., Rutter, A. P., Walz, K. A., \& Morschauser, P. A. 2009. Effects of a platinum- cerium bimetallic fuel additive on the chemical composition of diesel engine exhaust particles. Energy \& fuels, 23(10), 4974-4980.

[22] Arabaci, E., \& Orman, R. Ç. 2020. Experimental Investigation of the Use of Waste Engine Oil Improved with Manganese Additive as Fuel in a Diesel Power Generator. Environmental Progress \& Sustainable Energy, 1-14.

[23] Neeft, J. P. A., Jelles, S. J., Makkee, M., \& Moulijn, J. A. 1998. Copper catalysis for particulate removal from diesel exhaust gas. Copper fuel additives in combination with copper coatings. In Studies in surface science and catalysis (Vol. 116, pp. 655-666). Elsevier.

[24] Luman, J. R., Wehrman, B., Kuo, K. K., Yetter, R. A., Masoud, N. M., Manning, T. G., ... \& Bruck, H. A. 2007. Development and characterization of high performance solid propellants containing nano-sized 
energetic ingredients. Proceedings of the Combustion Institute, 31(2), 2089-2096.

[25] Kannan, G. R., Karvembu, R., \& Anand, R. 2011. Effect of metal based additive on performance emission and combustion characteristics of diesel engine fuelled with biodiesel. Applied energy, 88(11), 3694-3703.

[26] Prabu, A., \& Anand, R. B. 2016. Emission control strategy by adding alumina and cerium oxide nano particle in biodiesel. Journal of the Energy Institute, 89(3), 366-372.

[27] D'Silva, R., Vinoothan, K., Binu, K. G., Thirumaleshwara, B., \& Raju, K. 2016. Effect of titanium dioxide and calcium carbonate nanoadditives on the performance and emission characteristics of CI engine. Journal of Mechanical Engineering and Automation, 6(5A), 28-31.

[28] Karthikeyan, S., \& Prathima, A. 2016. Environmental effect of $\mathrm{CeO}_{2}$ nanoadditive on biodiesel. Energy Sources, Part A: Recovery, Utilization, and Environmental Effects, 38(24), 3673-3679.

[29] Sajith, V., Sobhan, C. B., \& Peterson, G. P. 2010. Experimental investigations on the effects of cerium oxide nanoparticle fuel additives on biodiesel. Advances in Mechanical Engineering, 2, 581407.

[30] Prabakaran, B. 2020. Influence of Butanol and Nano Titanium Oxide into Non Edible Cotton Seed Oil Biodiesel on the Performance of CI Engine (No. 202001-2134). SAE Technical Paper.

[31] Karthikeyan, S., Elango, A., \& Prathima, A. 2014. An environmental effect of GSO methyl ester with $\mathrm{ZnO}$ additive fuelled marine engine.

[32] Chandrasekaran, V., Arthanarisamy, M., Nachiappan, P., Dhanakotti, S., \& Moorthy, B. 2016. The role of nano additives for biodiesel and diesel blended transportation fuels. Transportation Research Part D: Transport and Environment, 46, 145-156.

[33] Venkatesan, H., Sivamani, S., Sampath, S., Gopi, V., \& Kumar, D. 2017. A comprehensive review on the effect of nano metallic additives on fuel properties, engine performance and emission characteristics. International Journal of Renewable Energy Research (IJRER), 7(2), 825-843.

[34] Rashedul, H. K., Masjuki, H. H., Kalam, M. A., Ashraful, A. M., Rahman, S. A., \& Shahir, S. A. 2014. The effect of additives on properties, performance and emission of biodiesel fuelled compression ignition engine. Energy Conversion and Management, 88, 348364.

[35] Imdadul, H. K., Masjuki, H. H., Kalam, M. A., Zulkifli, N. W. M., Rashed, M. M., Rashedul, H. K., ... \& Mosarof, M. H. 2015. A comprehensive review on the assessment of fuel additive effects on combustion behavior in CI engine fuelled with diesel biodiesel blends. RSC advances, 5(83), 67541-67567.

[36] Hosseinzadeh-Bandbafha, H., Tabatabaei, M., Aghbashlo, M., Khanali, M., \& Demirbas, A. 2018. A comprehensive review on the environmental impacts of diesel/biodiesel additives. Energy Conversion and Management, 174, 579-614.

[37] Elkelawy, M., El Shenawy, E. A., Panchal, H., Elbanna, A., Bastawissi, H. A. E., \& Sadasivuni, K. K. 2020. Experimental investigation on the influences of acetone organic compound additives into the diesel/biodiesel mixture in CI engine. Sustainable Energy Technologies and Assessments, 37, 100614.

[38] Damodharan, D., Sathiyagnanam, A. P., Rana, D., Saravanan, S., Kumar, B. R., \& Sethuramasamyraja, B. 2018. Effective utilization of waste plastic oil in a direct injection diesel engine using high carbon alcohols as oxygenated additives for cleaner emissions. Energy Conversion and Management, 166, 81-97.

[39] Kumar, M. V., Babu, A. V., \& Kumar, P. R. 2018. The impacts on combustion, performance and emissions of biodiesel by using additives in direct injection diesel engine. Alexandria Engineering Journal, 57(1), 509516.

[40] Yuvarajan, D., Pradeep, K., \& Magesh Kumar, S. 2016. Impact of oxygenated additives on performance characteristics of methyl ester in IC engine. In Applied Mechanics and Materials, Trans Tech Publications Ltd., 852, 724-728.

[41] Imtenan, S., Masjuki, H. H., Varman, M., Fattah, I. R., Sajjad, H., \& Arbab, M. I. 2015. Effect of n-butanol and diethyl ether as oxygenated additives on combustionemission-performance characteristics of a multiple cylinder diesel engine fuelled with diesel-jatropha biodiesel blend. Energy Conversion and Management, 94, 84-94.

[42] Verma, P., Stevanovic, S., Zare, A., Dwivedi, G., Chu Van, T., Davidson, M., ... \& Ristovski, Z. D. 2019. An overview of the influence of biodiesel, alcohols, and various oxygenated additives on the particulate matter emissions from diesel engines. Energies, 12(10), 1987.

[43] Kumar, C., Rana, K. B., Tripathi, B., \& Nayyar, A. 2018. A comparative study of oxygenated additives for diesel in compression ignition engine. International Journal of Renewable Energy Technology, 9(1-2), 1627.

[44] Moser, B. R. 2012. Efficacy of gossypol as an antioxidant additive in biodiesel. Renewable energy, 40(1), 65-70.

[45] Hess, M. A., Haas, M. J., Foglia, T. A., \& Marmer, W. N. 2005. Effect of antioxidant addition on NO $x$ 
emissions from biodiesel. Energy \& Fuels, 19(4), 17491754.

[46] Fazal, M. A., Suhaila, N. R., Haseeb, A. S. M. A., \& Rubaiee, S. 2018. Sustainability of additive-doped biodiesel: Analysis of its aggressiveness toward metal corrosion. Journal of Cleaner Production, 181, 508516.

[47] Ashok, B., Nanthagopal, K., Jeevanantham, A. K., Bhowmick, P., Malhotra, D., \& Agarwal, P. 2017. An assessment of calophyllum inophyllum biodiesel fuelled diesel engine characteristics using novel antioxidant additives. Energy Conversion and Management, 148, 935-943.

[48] Lamba, B. Y., Joshi, G., Tiwari, A. K., Rawat, D. S., \& Mallick, S. 2013. Effect of antioxidants on physicochemical properties of EURO-III HSD (high speed diesel) and Jatropha biodiesel blends. Energy, 60, 222229.

[49] Sutanto, H., Susanto, B. H., \& Nasikin, M. 2019. Solubility and antioxidant potential of a pyrogallol derivative for biodiesel additive. Molecules, 24(13), 2439.

[50] Dastagiri, D. and Govinda Rajulu, K.G. 2019. Experimental Investigation Of Ci Engine Fuelled With Karanji Oil As Biodiesel Using Pyrogallol As Antioxidant, International Research Journal of Engineering and Technology (IRJET), Volume: 06 Issue: 05, e-ISSN: 2395-0056.

[51] Ahanchi, M., Tabatabaei, M., Aghbashlo, M., Rezaei, K., Talebi, A. F., Ghaffari, A., ... \& Khounani, Z. 2018. Pistachio (Pistachia vera) wastes valorization: enhancement of biodiesel oxidation stability using hull extracts of different varieties. Journal of Cleaner Production, 185, 852-859.

[52] Balaji, S., Kapilan, N., \& Saravanan, R. 2016. Influence of propyl gallate antioxidant on performance and emissions of a ci fuelled with neem oil biodiesel. Journal of Biofuels, 7(2), 62-70.

[53] Sharma, A., \& Murugan, S. 2017. Effect of blending waste tyre derived fuel on oxidation stability of biodiesel and performance and emission studies of a diesel engine. Applied Thermal Engineering, 118, 365374.

[54] Ni, Z. H., Li, F. S., Wang, H., Wang, S., Gao, S. Y., \& Zhou, L. 2020. Antioxidative performance and oilsoluble properties of conventional antioxidants in rubber seed oil biodiesel. Renewable Energy, 145, 9398.

[55] Schober, S., \& Mittelbach, M. 2004. The impact of antioxidants on biodiesel oxidation stability. European Journal of Lipid Science and Technology, 106(6), 382389.
[56] Xin, J., Imahara, H., \& Saka, S. 2009. Kinetics on the oxidation of biodiesel stabilized with antioxidant. Fuel, 88(2), 282-286.

[57] Roy, M. M., Calder, J., Wang, W., Mangad, A., \& Diniz, F. C. M. 2016. Emission analysis of a modern Tier 4 DI diesel engine fueled by biodiesel-diesel blends with a cold flow improver (Wintron Synergy) at multiple idling conditions. Applied Energy, 179, 45-54.

[58] Verma, P., Sharma, M. P., \& Dwivedi, G. 2016. Evaluation and enhancement of cold flow properties of palm oil and its biodiesel. Energy Reports, 2, 8-13.

[59] Ranjan, A., Dawn, S. S., Jayaprabakar, J., Nirmala, N., Saikiran, K., \& Sriram, S. S. 2018. Experimental investigation on effect of $\mathrm{MgO}$ nanoparticles on cold flow properties, performance, emission and combustion characteristics of waste cooking oil biodiesel. Fuel, 220, 780-791.

[60] Shrestha, D. S., Van Gerpen, J., Thompson, J., \& Zawadzki, A. 2005. Cold flow properties of biodiesel and effect of commercial additives. In 2005 ASAE Annual Meeting (p. 1). American Society of Agricultural and Biological Engineers.

[61] Madiwale, S., Karthikeyan, A., \& Bhojwani, V. 2017, May. A comprehensive review of effect of biodiesel additives on properties, performance, and emission. In IOP Conf. Series: Materials Science and Engineering (Vol. 197, p. 012015).

[62] İleri, E., Karaoglan, A. D., \& Akpinar, S. 2020. Optimizing cetane improver concentration in biodieseldiesel blend via grey wolf optimizer algorithm. Fuel, 273, 117784.

[63] Hazrat, M. A., Rasul, M. G., \& Khan, M. M. K. 2015. Lubricity improvement of the ultra-low sulfur diesel fuel with the biodiesel. Energy Procedia, 75, 111-117. 